\title{
AP-1-Targeting Anti-Inflammatory Activity of the Methanolic Extract of Persicaria chinensis
}

\author{
Muhammad Jahangir Hossen, ${ }^{1,2}$ Seung Cheol Kim, ${ }^{3}$ Young-Jin Son, ${ }^{4}$ \\ Kwang-Soo Baek, ${ }_{1}$ Eunji Kim, ${ }^{1}$ Woo Seok Yang, ${ }^{1}$ Deok Jeong, ${ }^{1}$ Jae Gwang Park, \\ Han Gyung Kim, ${ }^{1}$ Woo-Jae Chung, ${ }^{1}$ Keejung Yoon, ${ }^{1}$ Chongsuk Ryou, ${ }^{5}$ Sang Yeol Lee, \\ Jong-Hoon Kim, ${ }^{7}$ and Jae Youl Cho' \\ ${ }^{1}$ Department of Genetic Engineering, Sungkyunkwan University, Suwon 440-746, Republic of Korea \\ ${ }^{2}$ Department of Animal Science, Patuakhali Science and Technology University, Patuakhali 8602, Bangladesh \\ ${ }^{3}$ Division of Gynecologic Oncology, Department of Obstetrics and Gynecology, Ewha Womans University Mokdong Hospital \\ College of Medicine, Ewha Womans University, Seoul 158-710, Republic of Korea \\ ${ }^{4}$ Department of Pharmacy, Sunchon National University, Suncheon 540-742, Republic of Korea \\ ${ }^{5}$ Department of Pharmacy, College of Pharmacy and Institute of Pharmaceutical Science and Technology, Hanyang University, \\ Ansan 426-791, Republic of Korea \\ ${ }^{6}$ Department of Life Science, Gachon University, Sungnam 461-701, Republic of Korea \\ ${ }^{7}$ Department of Veterinary Physiology, College of Veterinary Medicine, Biosafety Research Institute, \\ Chonbuk National University, Jeonju 561-756, Republic of Korea
}

Correspondence should be addressed to Jong-Hoon Kim; jhkim1@jbnu.ac.kr and Jae Youl Cho; jaecho@skku.edu

Received 8 January 2015; Revised 22 February 2015; Accepted 2 March 2015

Academic Editor: Cun-Zhi Liu

Copyright ( $) 2015$ Muhammad Jahangir Hossen et al. This is an open access article distributed under the Creative Commons Attribution License, which permits unrestricted use, distribution, and reproduction in any medium, provided the original work is properly cited.

\begin{abstract}
In traditional Chinese medicine, Persicaria chinensis L. has been prescribed to cure numerous inflammatory disorders. We previously analyzed the bioactivity of the methanol extract of this plant (Pc-ME) against LPS-induced NO and PGE 2 in RAW264.7 macrophages and found that it prevented $\mathrm{HCl} / \mathrm{EtOH}$-induced gastric ulcers in mice. The purpose of the current study was to explore the molecular mechanism by which Pc-ME inhibits activator protein- (AP-) 1 activation pathway and mediates its hepatoprotective activity. To investigate the putative therapeutic properties of Pc-ME against AP-1-mediated inflammation and hepatotoxicity, lipopolysaccharide- (LPS-) stimulated RAW264.7 and U937 cells, a monocyte-like human cell line, and an LPS/D-galactosamine(D-GalN-) induced acute hepatitis mouse model were employed. The expression of LPS-induced proinflammatory cytokines including interleukin- (IL-) $1 \beta$, IL-6, and tumor necrosis factor- $\alpha$ (TNF- $\alpha$ ) was significantly diminished by Pc-ME. Moreover, PcME reduced AP-1 activation and mitogen-activated protein kinase (MAPK) phosphorylation in both LPS-stimulated RAW264.7 cells and differentiated U937 cells. Additionally, we highlighted the hepatoprotective and curative effects of Pc-ME pretreated orally in a mouse model of LPS/D-GalN-intoxicated acute liver injury by demonstrating the significant reduction in elevated serum AST and ALT levels and histological damage. Therefore, these results strongly suggest that Pc-ME could function as an antihepatitis remedy suppressing MAPK/AP-1-mediated inflammatory events.
\end{abstract}

\section{Introduction}

Inflammation and innate immune response are considered beneficial for host survival [1] and are part of the complex biological response of living organisms to harmful stimuli, such as infection, cellular damage, and tissue injury [2]. Numerous cellular and biochemical alterations including downregulation of anti-inflammatory proteins and upregulation of proinflammatory gene products occur during inflammatory conditions to facilitate immune cell recruitment and to boost body's defensive mechanism [3,4]. Nevertheless, the instability of immune homeostasis and prolonged inflammatory response 
can result in the development of various chronic diseases such as autoimmune disorders, cancer, and vascular diseases $[5,6]$. Lipopolysaccharide (LPS) stimulates several proinflammatory mediator cytokines such as interferon, interleukin- $1 \beta$ (IL-1 $\beta$ ), interleukin-6 (IL-6), and tumor necrosis factor- $\alpha$ (TNF- $\alpha)[1,7,8]$.

During LPS-induced inflammation, LPS binds to toll-like receptor 4 (TLR4) and stimulates the recruitment of both cytoplasmic MyD88 and TRIF adaptor proteins, which activate mitogen-activated protein kinase (MAPK) signaling [9]. The MAPK family consists of extracellular signal-regulated kinase (ERK), c-Jun N-terminal kinase (JNK), and p38. Continual activation of the MAPK signaling pathway has been shown to increase the activation of activator protein- (AP-) 1 , a heterodimeric transcription factor, composed of c-Fos, $\mathrm{c}$ Jun, ATF, and JDP families [10]. Activated AP-1 eventually upregulates the transcription of inflammatory genes containing the 12-O-tetradecanoylphorbol-13-acetate (TPA) DNA response element (TRE, $5^{\prime}$-TGAG/CTCA-3 ${ }^{\prime}$ ) [11]. Indeed, it is known that the development of numerous human inflammatory diseases is accompanied with the activation of AP-1 [12]. Hence, targeting MAPK/AP-1 pathways is an attractive anti-inflammatory therapeutic approach.

Hepatitis, a liver disease associated with severe hepatocyte damage, is highly associated with acute or chronic inflammation caused by other infections, alcohol ingestion, certain medications, some industrial organic solvents and plants, and autoimmune diseases $[13,14]$. Liver inflammation recruits numerous types of immune cells such as natural killer cells, T cells, dendritic cells, and macrophages [13]. Like other inflammatory diseases, the hepatic macrophages display prime pathophysiological roles in inducing liver injury by enormous production of reactive oxygen/nitrogen species and proinflammatory cytokines such as TNF- $\alpha$, IL- $1 \beta$, and IL-6 [13]. LPS/D-galactosamine- (D-GalN-) induced hepatitis in mice is a classical experimental model of severe liver injury involving the production of inflammatory cytokines and recruitment of inflammatory cells, leading to liver damage and dysfunction $[15,16]$.

Persicaria chinensis L. (Polygonaceae) is one of the representative medicinal plants that are widely used in tropical and subtropical Eastern Asia [17]. The Malaysian Chinese community and Tamang community of Nepal have been known to prescribe this plant to treat various lung diseases $[18,19]$. Malaysian communities and Indian tribes have used the methanolic extract of leaves to cope with infectious diseases and ulcers $[17,20]$. In addition, numerous previous studies have reported the importance of $P$. chinensis as an anti-inflammatory plant [18-20], but the molecular ethnopharmacological evidence is still ambiguous. Recently, we demonstrated that $95 \%$ methanol extract of the aerial parts of this plant (Pc-ME) can effectively ameliorate inflammatory responses in $\mathrm{HCl} / \mathrm{EtOH}$-induced gastritis and TLR4-activated macrophages through the suppression of Syk/Src/NF- $\kappa$ B [17]. Previously, it was stated that MAPKs play an important role in the regulation of LPS-induced inflammation by controlling AP-1 activation [21] and are strongly linked to the induction of hepatitis [22, 23]. This prompted us to further examine the molecular inhibitory effects of Pc-ME on the AP-1 pathway and we assumed that this extract may be capable of attenuating hepatitis symptoms. To conquer our hypothesis, we used lipopolysaccharide- (LPS-) treated macrophages RAW264.7 cell line and human pleura/pleural effusion monocyte-like cell line U937 and LPS/D-GalN-induced hepatitis mouse model. Holistic molecular approaches including reporter gene assays, immunoprecipitation analysis, and histopathological and hematopathological investigation were also used to confirm our assumption.

\section{Materials and Methods}

2.1. Materials. Quercetin, 3-(4,5-dimethylthiazol-2-yl)-2,5diphenyltetrazolium bromide (MTT), and lipopolysaccharide (LPS, E. coli 0111:B4) were purchased from Sigma Chemical Co. (St. Louis, MO, USA). Luciferase constructs containing promoters for AP-1 were a gift from Professor Chung, Hae Young (Pusan National University, Pusan, Korea). Fetal bovine serum (FBS) and RPMI1640 were obtained from Gibco (Grand Island, NY, USA). RAW264.7 cells, a BALB/cderived murine macrophage cell line (number TIB-71); U937 cells, a human pleura/pleural effusion monocyte-like cell line (number CRL-1593.2); and HEK293 cells, a human embryonic kidney cell line (number CRL-1573), were purchased from American Tissue Culture Center (Rockville, MD, USA). Luciferase constructs containing binding sites for AP-1 were used as reported previously $[24,25]$. All other chemicals were obtained from Sigma. Phosphospecific or total antibodies to lamin A/C, c-Fos, c-Jun, ERK, JNK, p38, MEK1/2, MKK4, and $\beta$-actin used in this study were purchased from Cell Signaling Technology (Beverly, MA, USA).

2.2. Pc-ME Preparation. Pc-ME (Code number: PBID 110601) was obtained from the Plant Extract Bank in the Plant Diversity Research Center (Daejeon, Korea; http://extract .kribb.re.kr/extract/f.htm, e-mail: mplantext@kribb.re.kr), as reported previously [17].

2.3. Drug Treatment. In case of cellular experiments, Pc-ME prepared in $100 \%$ DMSO at a concentration of $100 \mathrm{mg} / \mathrm{mL}$ was diluted with culture medium. For animal experiment, Pc-ME $(200 \mathrm{mg} / \mathrm{kg})$ was resuspended in $1 \%$ sodium carboxymethylcellulose (CMC), as reported previously [26], and LPS $(10 \mu \mathrm{g} / \mathrm{kg}) / \mathrm{D}-\mathrm{GalN}(1 \mathrm{~g} / \mathrm{kg})$ was dissolved in phosphatebuffered saline (PBS).

\subsection{In Vitro Studies}

2.4.1. Cell Culture. The cancerous macrophage line RAW264.7 and human pleura/pleural effusion monocytelike cell line U937 were maintained in RPMI1640, while human embryonic kidney cell line HEK293 was cultured in DMEM medium, each supplemented with $10 \%$ heatinactivated FBS, glutamine, and penicillin/streptomycin at $37^{\circ} \mathrm{C}$ during 5\% $\mathrm{CO}_{2}$. Before Pc-ME treatment, U937 cells were treated with PMA $(20 \mathrm{nM})$ for $12 \mathrm{~h}$. 
TABLE 1: RT-PCR and real-time PCR primers used in this study.

(a) RT-PCR primers

\begin{tabular}{lll}
\hline Name & & \multicolumn{1}{c}{ Sequence $\left(5^{\prime}\right.$ to $\left.3^{\prime}\right)$} \\
\hline \multirow{2}{*}{ TNF- $\alpha$} & F & TTGACCTCAGCGCTGAGTTG \\
& R & CCTGTAGCCCACGTCGTAGC \\
\hline \multirow{2}{*}{ IL-6 } & F & GGAAATCGTGGAAATGAG \\
& R & GCTTAGGCATAACGCACT \\
\hline \multirow{2}{*}{ IL-1 $\beta$} & F & CAGGATGAGGACATGAGCAC \\
& R & CTCTGCAGACTCAAACTCCA \\
\hline \multirow{2}{*}{ GAPDH } & F & CAA TGA ATA CGG CTA CAG CAA C \\
& R & AGG GAG ATG CTC AGT GTT GG \\
\hline
\end{tabular}

(b) Real-time PCR primers

\begin{tabular}{lll}
\hline Name & & \multicolumn{1}{c}{ Sequence $\left(5^{\prime}\right.$ to $\left.3^{\prime}\right)$} \\
\hline \multirow{2}{*}{ TNF- $\alpha$} & $\mathrm{F}$ & GAAAGCATGATCCGGGACGTG \\
& $\mathrm{R}$ & GATGGCAGAGAGGAGGTTGAC \\
\hline \multirow{2}{*}{ IL-6 } & F & AAGCCAGAGCTGTGCAGATGAGTA \\
& $\mathrm{R}$ & CTTGGTCACCGACGTCCTGT \\
\hline \multirow{2}{*}{ IL-1 $\beta$} & $\mathrm{F}$ & CCGACCACCACTACAGCAAG \\
& $\mathrm{R}$ & GGGCAGGGAACCAGCATCTT \\
\hline \multirow{2}{*}{ GAPDH } & F & TGGAAGGACTCATGACCACA \\
& $\mathrm{R}$ & AGGGGTCTACATGGCAACTG \\
\hline
\end{tabular}

2.4.2. Cell Viability Test. After preincubation of RAW264.7, HEK 293, and U937 cells $\left(1 \times 10^{6}\right.$ cells $\left./ \mathrm{mL}\right)$ for $18 \mathrm{~h}$, Pc-ME (0, 100,200 , and $300 \mu \mathrm{g} / \mathrm{mL}$ ) was added to the cell suspensions and incubated for $24 \mathrm{~h}$. The effect of Pc-ME on cell viability was tested by a conventional MTT assay, according to previous reports $[27,28]$. In brief, at $3 \mathrm{~h}$ prior to culture termination, $10 \mu \mathrm{L}$ of MTT solutions $(10 \mathrm{mg} / \mathrm{mL}$ in phosphatebuffered saline, $\mathrm{pH}$ 7.4) was added and cells were continuously cultured until assay termination. The incubation was halted by the addition of $15 \%$ sodium dodecyl sulphate to each well to solubilize the formazan and absorbance at 570 $630 \mathrm{~nm}\left(\mathrm{OD}_{570-630}\right)$ was measured using a Spectramax 250 microplate reader.

2.4.3. mRNA Analysis by Semiquantitative Reverse Transcriptase-Polymerase Chain Reaction (RT-PCR) and RealTime PCR. To determine mRNA expression levels of proinflammatory cytokine genes, RAW264.7 or U937 cells were exposed to Pc-ME $(0,100$, and $300 \mu \mathrm{g} / \mathrm{mL})$ for $30 \mathrm{~min}$ (RAW264.7 cells) or $3 \mathrm{~h}$ (U937 cells) before incubation with LPS $(1 \mu \mathrm{g} / \mathrm{mL}$ for RAW264.7 cells and $10 \mu \mathrm{g} / \mathrm{mL}$ for U937 cells) for $6 \mathrm{~h}$ (RAW264.7 cells) or $12 \mathrm{~h}$ (U937 cells). Total RNA was prepared with TRIzol reagent (Gibco) according to the manufacturer's instructions and stored at $-70^{\circ} \mathrm{C}$ for later use. Semiquantitative RT-PCR and real-time PCR reactions were also carried out, according to previous report [29]. The primers (Bioneer, Seoul, Korea) used in this study are listed in Table 1.

2.4.4. Plasmid Transfection and Luciferase Reporter Gene Activity Assay. HEK293 cells $\left(1 \times 10^{6}\right.$ cells $/ \mathrm{mL}$ in 12 -well plates) were transfected with plasmids ( $\beta$-galactosidase and
AP-1-Luc) under cotransfection with an inducing molecule (MyD88, TRIF, or PMA) using the polyethyleneimine (PEI) method. The cells were treated with Pc-ME $(0,100,200$, and $300 \mu \mathrm{g} / \mathrm{mL})$ or quercetin $(0,20,40$, and $80 \mu \mathrm{M})$ for $12 \mathrm{~h}$ until harvesting. Luciferase activity was determined by the Luciferase Assay System (Promega, Madison, WI, USA), as previously reported [30,31].

\subsection{In Vivo Studies}

2.5.1. Animals. Male C57BL/6 mice (6-8 weeks old, 17$21 \mathrm{~g}$ ) were purchased from DAEHAN BIOLINK (Chungbuk, Korea) and were housed in groups of 6-8 mice under a $12 \mathrm{~h}$ light/dark cycle (lights on at 6 a.m.). Water and pellet diets (Samyang, Daejeon, Korea) were supplied ad libitum. Animals were cared for in accordance with the guidelines issued by the National Institute of Health for the Care and Use of Laboratory Animals (NIH Publication 80-23, revised in 1996). Studies were performed in accordance with guidelines established by the Institutional Animal Care and Use Committee at Sungkyunkwan University (Suwon, Korea; approval ID: SKKUBBI 12-6-1).

2.5.2. LPS/D-GalN-Induced Hepatitis Mouse Model. A model of experimental liver inflammation was induced by LPS injection according to a previously published method [32]. Briefly, five-week-old C57BL/6 mice were treated orally with Pc-ME $(200 \mathrm{mg} / \mathrm{kg})$ once a day for six days with the aid of crop needles. One hour after the final administration of Pc-ME, LPS $(10 \mu \mathrm{g} / \mathrm{kg})$ and D-GalN $(1 \mathrm{~g} / \mathrm{kg})$ were injected intraperitoneally. Each animal was anesthetized with an overdose of urethane 1 hour after administration of hepatitis inducers, and blood was collected by cardiac puncture. The livers were then excised and gently rinsed with PBS. Serum was obtained by centrifugation of blood at $3,000 \mathrm{rpm}$ for $15 \mathrm{~min}$. The levels of serum alanine aminotransferase (ALT) and aspartate aminotransferase (AST) were measured with a Roche Modular spectrophotometric autoanalyzer.

2.5.3. Histopathology. The histopathological observation was also performed as previously described [33]. Briefly, tissue samples taken from the liver of the mice at $8 \mathrm{~h}$ after challenge with LPS and D-GalN were fixed with $10 \%$ formalin in PBS and then embedded in paraffin. Approximately $4 \mu \mathrm{m}$ thin tissue sections were stained with hematoxylin and eosin for histopathological examination.

2.6. Preparation of Total Lysates, Nuclear Extracts, and Immunoblotting. In vivo samples (liver tissues from mice treated with Pc-ME $(0$ and $200 \mathrm{mg} / \mathrm{kg}))$ or in vitro samples (RAW264.7 cells $\left(5 \times 10^{6}\right.$ cells $\left./ \mathrm{mL}\right)$ stimulated with LPS for various time points $(2,3,5,15,30$, and $60 \mathrm{~min})$ in the presence or absence of Pc-ME (0 to $300 \mu \mathrm{g} / \mathrm{mL}$ ) or PMA-treated U937 cells stimulated with LPS for 30 and 60 min during Pc-ME $(0$ and $300 \mu \mathrm{g} / \mathrm{mL}$ ) exposure) were washed three times in cold PBS with $1 \mathrm{mM}$ sodium orthovanadate and lysed by a sonicator or a Tissuemizer in lysis buffer $(20 \mathrm{mM}$ Tris- $\mathrm{HCl}$, pH 7.4, $2 \mathrm{mM}$ EDTA, $2 \mathrm{mM}$ ethyleneglycotetraacetic acid, $50 \mathrm{mM} \beta$-glycerophosphate, $1 \mathrm{mM}$ sodium orthovanadate, 
$1 \mathrm{mM}$ dithiothreitol, $1 \%$ Triton X-100, 10\% glycerol, $10 \mu \mathrm{g} / \mathrm{mL}$ aprotinin, $10 \mu \mathrm{g} / \mathrm{mL}$ pepstatin, $1 \mathrm{mM}$ benzamide, and $2 \mathrm{mM}$ PMSF) for $30 \mathrm{~min}$ with rotation at $4^{\circ} \mathrm{C}$. The lysates were clarified by centrifugation at $16,000 \times \mathrm{g}$ for $10 \mathrm{~min}$ at $4^{\circ} \mathrm{C}$ and stored at $-20^{\circ} \mathrm{C}$ until needed.

Nuclear extracts were prepared in a three-step procedure with RAW264.7 cells stimulated with LPS for 15, 30, 60, and $120 \mathrm{~min}$ in the presence or absence of Pc-ME (0 and $300 \mu \mathrm{g} / \mathrm{mL}$ ), as reported previously [34]. The cells were collected with a rubber policeman, washed with $1 \times \mathrm{PBS}$, and lysed in $500 \mu \mathrm{L}$ lysis buffer containing $50 \mathrm{mM} \mathrm{KCl}, 0.5 \%$ Nonidet P-40, 25 mM HEPES (pH 7.8), 1 mM phenylmethylsulfonyl fluoride, $10 \mu \mathrm{g} / \mathrm{mL}$ leupeptin, $20 \mu \mathrm{g} / \mathrm{mL}$ aprotinin, and $100 \mu \mathrm{M}$ 1,4-dithiothreitol (DTT) on ice for $4 \mathrm{~min}$. Cell lysates were then centrifuged at $19,326 \times \mathrm{g}$ for $1 \mathrm{~min}$ in a microcentrifuge. In the second step, the pellet (the nuclear fraction) was washed once in washing buffer, which was the same as the lysis buffer but without Nonidet P-40. In the final step, nuclei were treated with an extraction buffer (lysis buffer containing $500 \mathrm{mM} \mathrm{KCl}$ and $10 \%$ glycerol). The nuclei/extraction buffer mixture was frozen at $-80^{\circ} \mathrm{C}$ and then thawed on ice and centrifuged at $19,326 \times \mathrm{g}$ for $5 \mathrm{~min}$. The supernatant was collected as a nuclear extract.

Soluble cell lysates or the nuclear extracts were immunoblotted and total or phosphorylated protein levels of transcription factors (lamin A/C, c-Fos, and c-Jun), ERK, JNK, p38, $\mathrm{MEK} 1 / 2, \mathrm{MKK} 4$, and $\beta$-actin (as a control) were visualized, according to a previously published method [35].

2.7. Statistical Analysis. All data are expressed as the mean \pm standard deviation (SD) of an experiment performed with six (Figures 1, 2, and 6) or three (Figures 3, 4, and 5) samples for in vitro test and six mice of each group for in vivo tests (Figure 5). Statistical comparisons were carried out by ANOVA/Scheffe's post hoc test and Kruskal-Wallis/Mann-Whitney tests. A $P$ value $<0.05$ was considered statistically significant. All statistical tests were performed with the computer program SPSS 17 for Windows XP. Similar results were found in an additional independent set of in vitro and in vivo experiments performed under the same conditions.

\section{Results}

3.1. Effect of Pc-ME on Cell Viability. As shown in Figure 1, the viability of RAW264.7, HEK293, and U937 cells was not significantly affected by treatment with Pc-ME up to $300 \mu \mathrm{g} / \mathrm{mL}$ compared with that of the cells receiving no LPS treatment.

3.2. Effect of Pc-ME on the Transcriptional Activation of AP-1. We next performed a transfection experiment with the AP-1Luc construct and HEK293 cells and used luciferase assays to examine whether Pc-ME suppressed the functional activation of AP-1. We found that AP-1-mediated luciferase activity was increased by PMA treatment (up to 50-fold) or cotransfection with adaptor molecules TRIF (up to 4.5-fold) and MyD88 (up to 8 -fold), whereas Pc-ME treatment significantly $(P<0.01)$ and dose-dependently $(100,200$, and $300 \mu \mathrm{g} / \mathrm{mL})$ inhibited

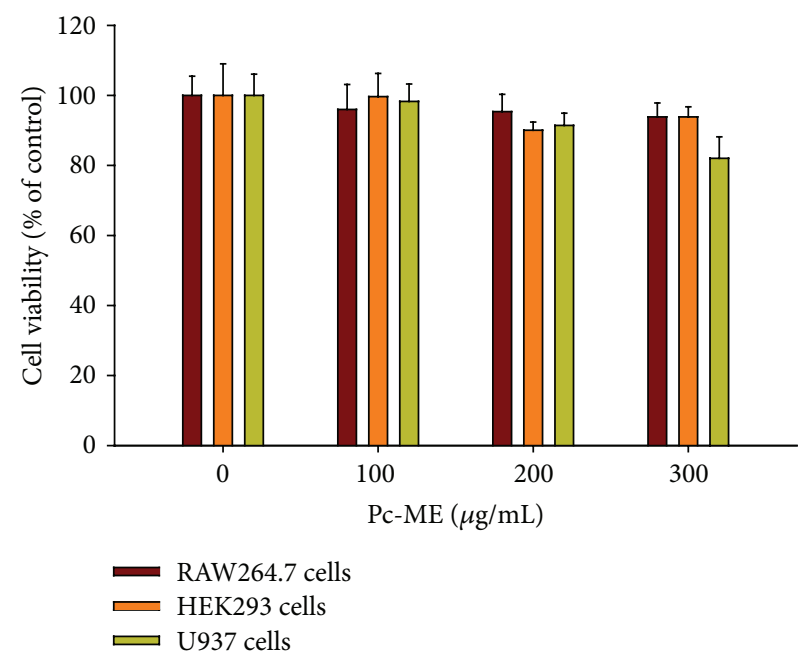

FIGURE 1: Cell viability of RAW264.7, HEK293, and U937 cells was determined using the MTT assay.

this upregulation (Figure 2), suggesting that AP-1 activation is a major pharmacological target of Pc-ME.

AP-1 transcription factor is known to have a major regulatory role in inflammatory gene expression, so we examined the suppressive effect of Pc-Me on the activation and translocation of AP-1 after treatment with Pc-ME. Figure 3(a) shows the increase in nuclear level of the AP-1 c-Fos subunit due to time-dependent inhibition by Pc-ME $(15,30,60$, and $120 \mathrm{~min}$ ). Similar time-dependent (30 and $60 \mathrm{~min}$ ) inhibitory patterns of c-Fos expression were confirmed by whole lysate extraction from U937 cells (Figure 3(b)).

3.3. Effects of Pc-ME on LPS-Induced Proinflammatory Cytokine Production. Lee et al. [33] and Feldmann [36] have suggested that TNF- $\alpha$, IL- $1 \beta$, and IL- 6 are crucial mediators of the development of inflammatory diseases. We further investigated the effect of Pc-ME on proinflammatory gene expression in RAW264.7 cells and U937 cells after LPS treatment. RT-PCR results demonstrated a significant concentrationdependent decrease in LPS-induced upregulation of TNF- $\alpha$, IL-1 $\beta$, and IL- 6 mRNA levels in Pc-ME-treated RAW264.7 cells (Figure 3(c)). In parallel, real-time PCR (Figures 3(d) to 3(f)) in U937 cells clearly showed that LPS was able to induce the upregulation of proinflammatory cytokines such as TNF- $\alpha$ up to 6,460 -fold, IL- $1 \beta$ up to 1,360 -fold, and IL- 6 up to 20 -fold, whereas Pc-ME $(300 \mu \mathrm{g} / \mathrm{mL})$ strongly $(P<0.01)$ inhibited this.

3.4. Effect of Pc-ME on Upstream Signaling for AP-1 Activation. It has been reported [37] that phosphorylation of MAPK (ERK, JNK, and p38) plays a pivotal role in the regulation of LPS-induced inflammatory mediators, so we performed Western blot analysis to determine the inhibitory activity of Pc-ME on proinflammatory mediators. LPS significantly elevated the phosphorylation of ERK, JNK, and p38, whereas Pc-ME pretreatment strongly and time-dependently $(5,15,30$, and $60 \mathrm{~min})$ suppressed LPS-induced phosphorylation of JNK and ERK but not that of p38 (Figure 4(a), 


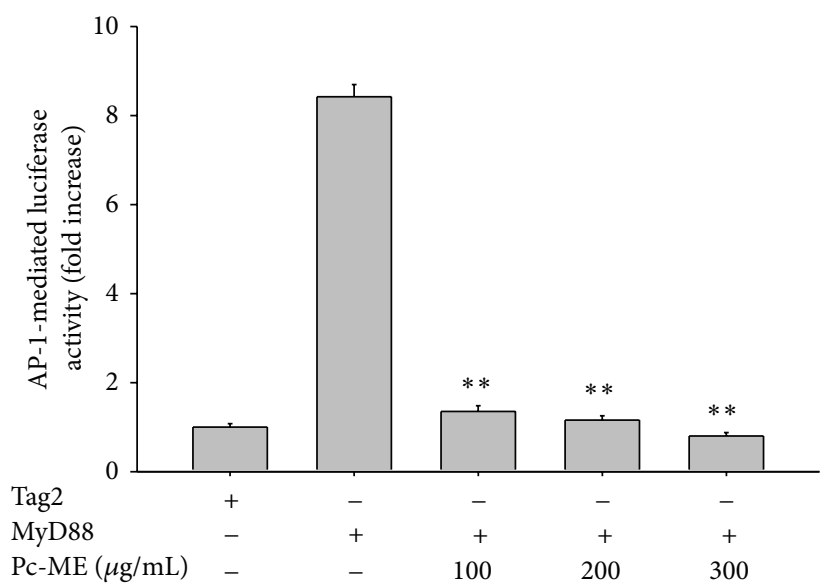

(a)

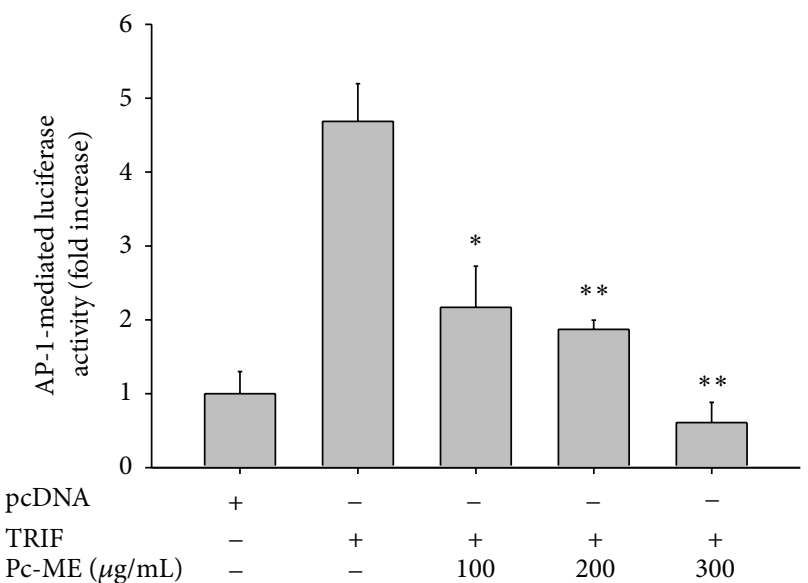

(b)

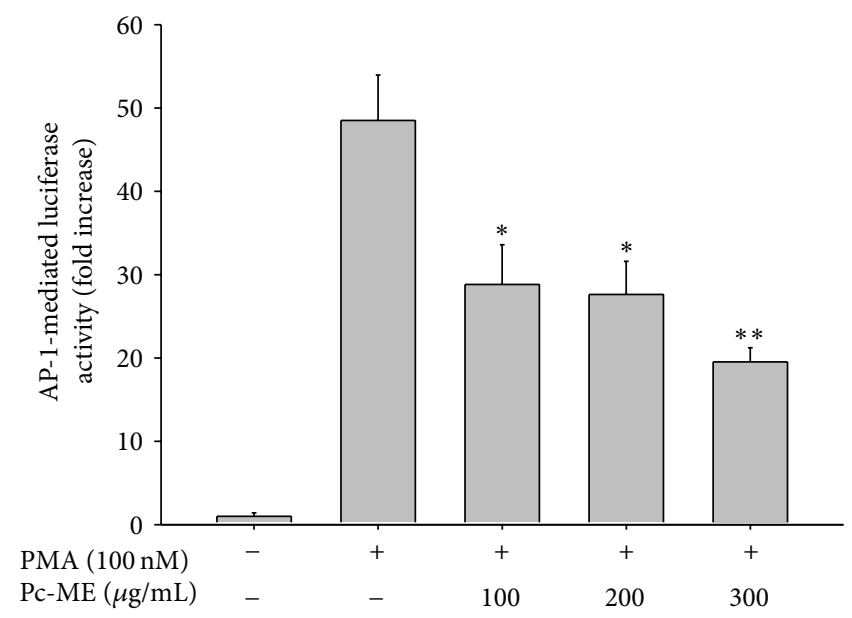

(c)

Figure 2: Effect of Pc-ME on the reporter gene assay. The promoter binding activity of the transcription factor AP-1 was analyzed using a reporter gene assay in HEK293 cells transfected with plasmid constructs AP-1-Luc $(1 \mu \mathrm{g} / \mathrm{mL})$ or $\beta$-gal (as a transfection control) with $1 \mu \mathrm{g} / \mathrm{mL}$ of MyD88 (a) or TRIF (b) and 100 nM PMA (c) in the presence of Pc-ME. Luciferase activity was measured using a luminometer. ${ }^{* *} P<0.01$ compared with control.

left panel) in RAW264.7 cells. The right panel in Figure 4(a) shows that Pc-ME (50, 100, 200, and $300 \mu \mathrm{g} / \mathrm{mL})$ dosedependently blocked the phosphorylation of ERK and JNK, which validates our experimental findings and confirms our expectations. Upstream signaling enzymes (MEK1/2 and MKK4) contributing to ERK and JNK phosphorylation were appreciably blocked by Pc-ME at 2, 3, and 5 min of LPS treatment (Figure 4(b)), which demonstrates that MEK1/2 and MKK4 might be targeted by Pc-ME in its AP-1-suppressive anti-inflammatory actions in LPS-stimulated RAW264.7 cells. In concurrence with our LPS/D-GalN-treated mice hepatitis experimental model, the upregulation of phosphorylated MKK4 and c-Fos in the liver tissue was markedly suppressed by orally administered Pc-ME (Figure 5(d)).

\subsection{Hepatoprotective Effect of Pc-ME on LPS/D-GalN-Induced} Liver Injury in Mice. We used a mouse model of LPS/DGalN-induced liver injury to investigate the in vivo hepatoprotective effect of Pc-ME. LPS/D-GalN-triggered ALT
(14,000 U/L) and AST (10,000 U/L) protein levels were significantly $(P<0.01)$ decreased by Pc-ME (Figures 5(a) and 5(b)). Moreover, histopathological analysis demonstrated that the liver sections of the LPS/D-GalN group displayed more neutrophil recruitment, as assessed by bigger sized and increased numbers dark spots (see arrows in Figure 5(c)), compared with the saline-treated control groups; in contrast, the Pc-ME-treated groups exhibited lower neutrophil numbers (Figure 5(c)), which demonstrates the strong hepatoprotective activity of Pc-ME.

3.6. Effect of Quercetin on AP-1 Activity. Cotransfection with the adaptor molecule MyD88 enhanced AP-1-mediated luciferase activity by 4.5 -fold; quercetin, a major flavonoid from Pc-ME [17], significantly $(P<0.01)$ and dosedependently inhibited this upregulation (Figure 6), which demonstrates that AP-1 activation is a major pharmacological target of Pc-ME and its ingredient quercetin. 


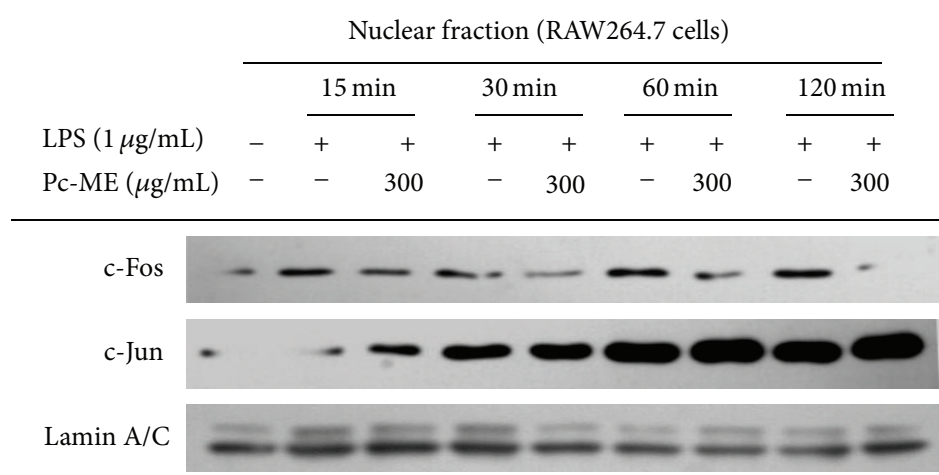

(a)

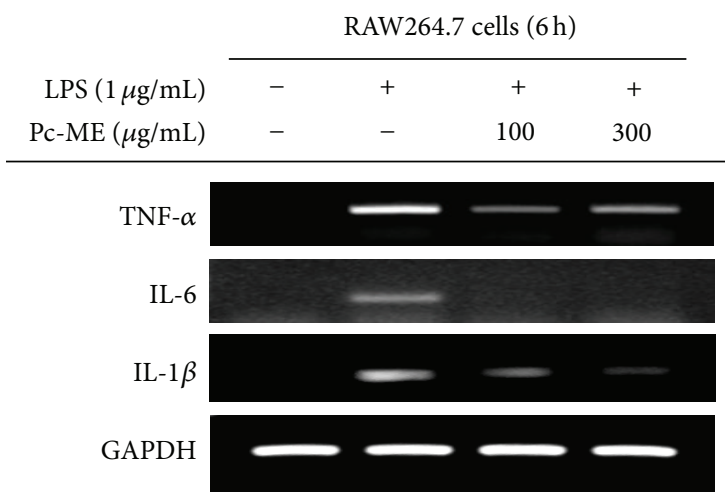

(c)

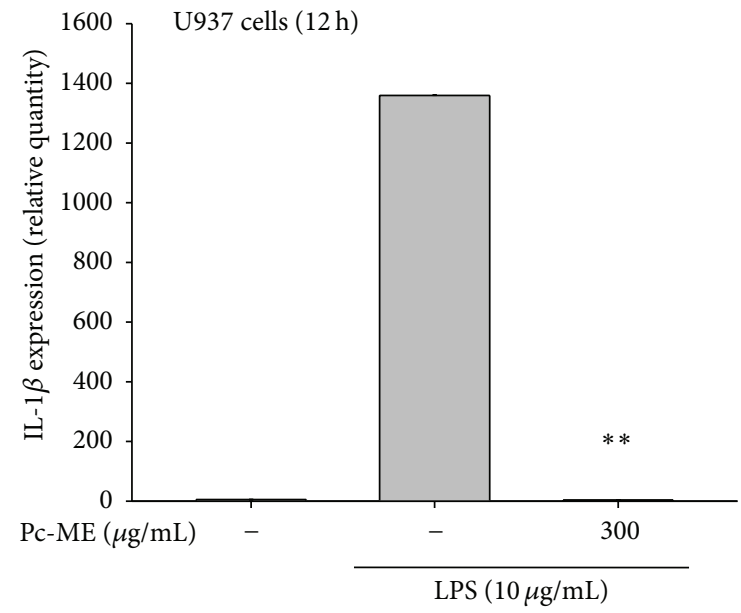

(e)

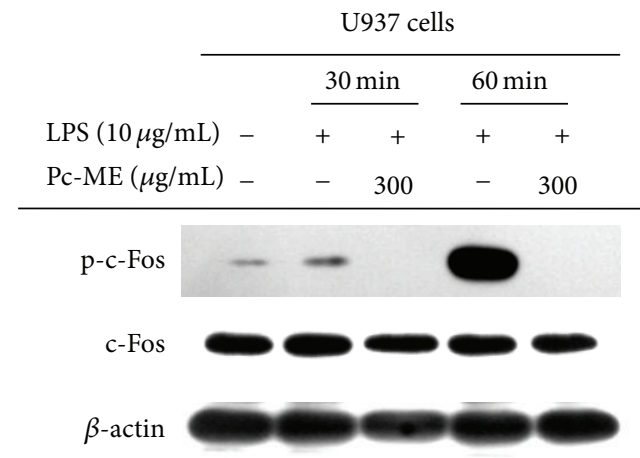

(b)

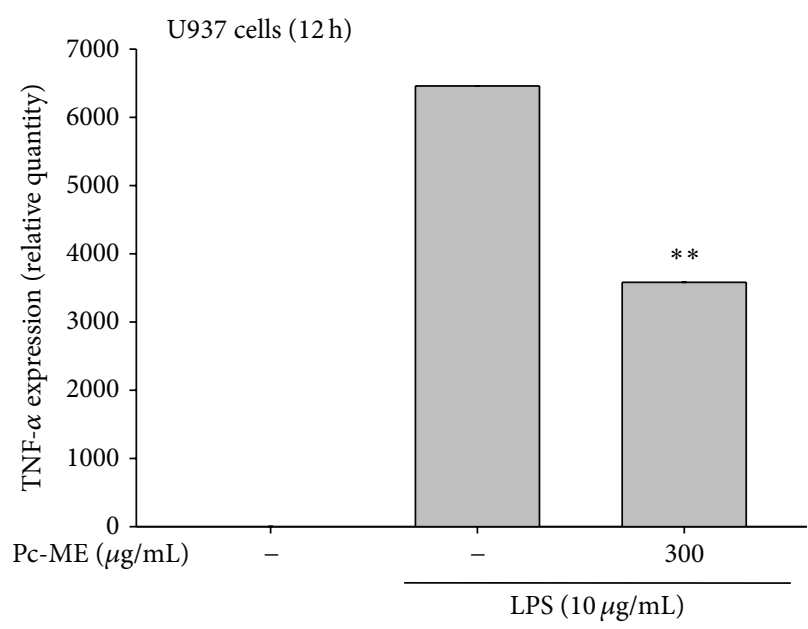

(d)

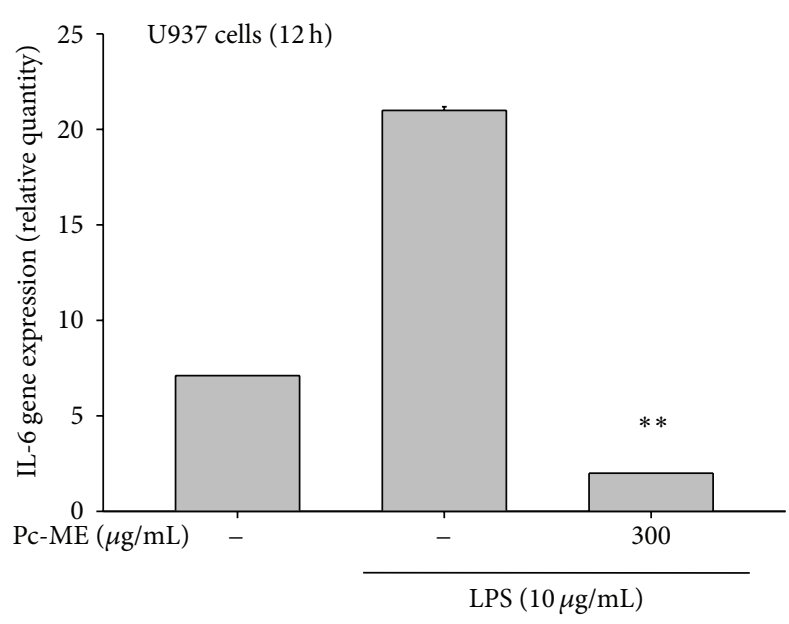

(f)

Figure 3: Effect of Pc-ME on the activation of proinflammatory cytokines and transcriptional regulation. (a) Levels of c-Fos, c-Jun, and lamin A/C in nuclear fractions were determined by immunoblot analysis in RAW264.7 cells. (b) Phospho- or total protein levels of c-Fos and $\beta$-actin in cell lysates were determined by immunoblot analysis in U937 cells. (c) mRNA levels of TNF- $\alpha$, IL-1 $\beta$, IL- 6 , and GAPDH were determined by semiquantitative RT-PCR in RAW264.7 cells. (d-f) mRNA levels of TNF- $\alpha$, IL-1 $\beta$, and IL- 6 were determined by real-time RT-PCR in U937 cells.

\section{Discussion}

While $P$. chinensis has high ethnopharmacological worth in Eastern Asian countries, the molecular mechanisms underlying its anti-inflammatory activity are still unknown. Recently, our studies have revealed that $P$. chinensis methanol extract exhibits strong antigastritis activity and is able to block NF- $\kappa$ B activation via suppression of Src and Syk 


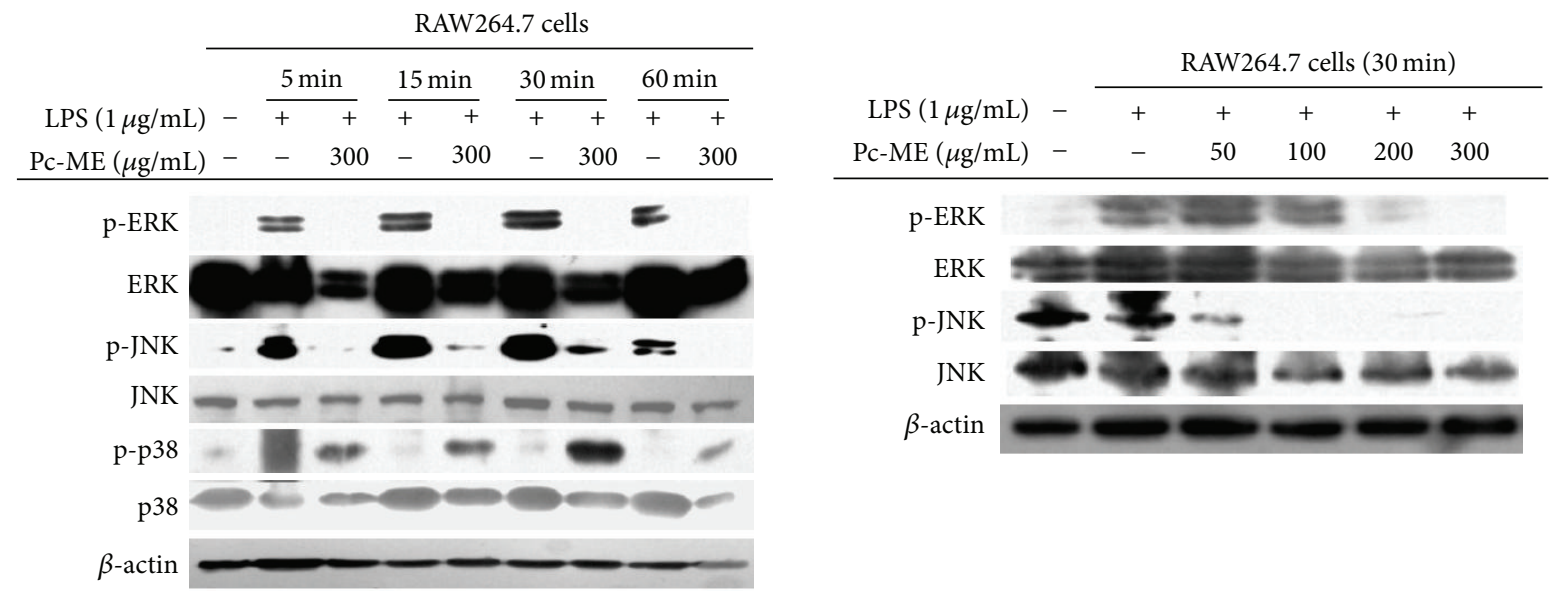

(a)

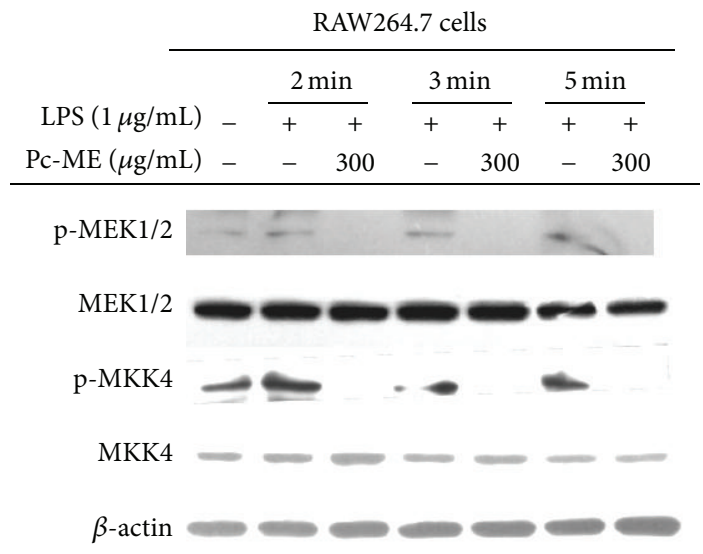

(b)

FIGURE 4: Effect of Pc-ME on the activation of upstream signaling enzymes of AP-1 translocation. (a and b) Phospho- and total protein levels of ERK, JNK, p38, MEK1/2, MKK4, and $\beta$-actin in cell lysates were determined by immunoblotting analysis.

activities [17]. However, Src/Syk-linked activation of NF- $\kappa \mathrm{B}$ is not the only important regulatory loop of inflammatory reaction. In addition, it has been reported that AP-1 activated by MAPK plays another crucial roles in inflammatory reaction $[11,38,39]$. In the present study, therefore, we aimed to elucidate inhibitory mechanism of Pc-ME on AP-1 function in vitro and in vivo by using LPS-activated macrophages and LPS/D-GalN-triggered hepatitis model.

It has been shown that reporter gene luciferase assay performed in conjunction with HEK293 cells transfected with Luc constructs and adaptor molecules, essential for TLR signaling [40], is a reasonable approach for studying functional activation of transcription factors [41, 42]. Therefore, to examine the ability of Pc-ME to suppress AP-1 function, we first employed the luciferase assay using HEK293 cells transfected with the AP-1-Luc construct. As expected, AP1-mediated luciferase activity was enhanced up to 4.5- to 48.5-fold by PMA treatment or cotransfection with adaptor molecules (TRIF and MyD88), and Pc-ME notably inhibited this upregulation in a dose-dependent manner (Figure 2). Moreover, nuclear translocation of c-Fos was reduced by Pc$\mathrm{ME}$ treatment in a time-dependent manner (Figure 3(a)), implying that AP-1 family of transcription factors can be functionally inactivated and that their upstream kinases responsible for AP-1 phosphorylation can be targeted.

Several earlier reports have suggested that several proinflammatory cytokines such as TNF- $\alpha$, IL- $1 \beta$, and IL- 6 play an important role in boosting proinflammatory roles of macrophages [43-45]. We therefore further tested whether these proinflammatory cytokines can be also suppressed by Pc-ME using LPS-treated RAW264.7 cells. The mRNA analysis of these cytokines by RT-PCR in RAW264.7 cells (Figure 3(c)) and by real-time PCR in U937 cells (Figures $3(\mathrm{~d})-3(\mathrm{f}))$ revealed that mRNA levels of TNF- $\alpha$, IL- $1 \beta$, and IL-6 were strongly upregulated by LPS treatment, while PcME significantly and dose-dependently (100 and $300 \mu \mathrm{g} / \mathrm{mL})$ inhibited such upregulation, indicating that AP-1 suppression by Pc-ME may be associated with blockade of these proinflammatory cytokines as well as its suppressive activity on the expression of iNOS and COX-2 [17]. In fact, a number of studies have also reported that many known herbal medicines such as Polygonum hydropiper, Pistacia integerrima, Phaseolus angularis, Morus bombycis Koidzumi, and Sanguisorba officinalis possess AP-1 pathway inhibitory activity as their 


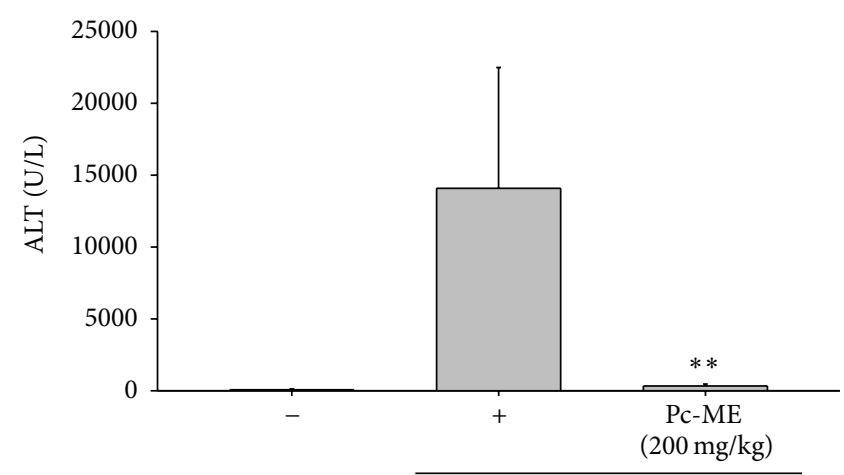

LPS $(10 \mu \mathrm{g} / \mathrm{kg}) / \mathrm{D}-\mathrm{GalN}(1 \mathrm{mg} / \mathrm{kg})$

(a)

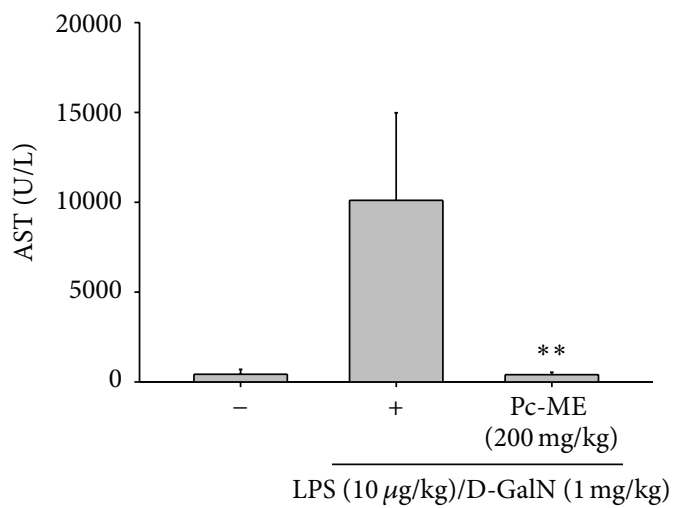

(b)

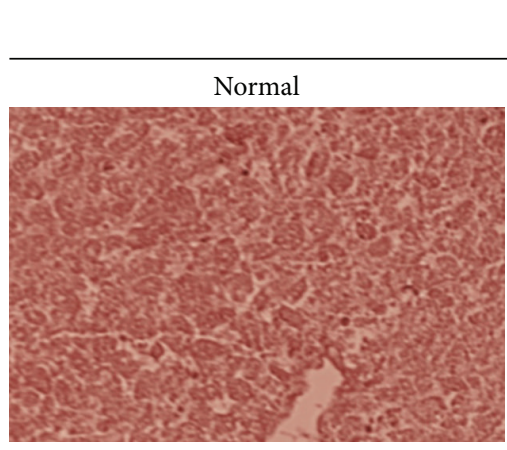

H\&E staining
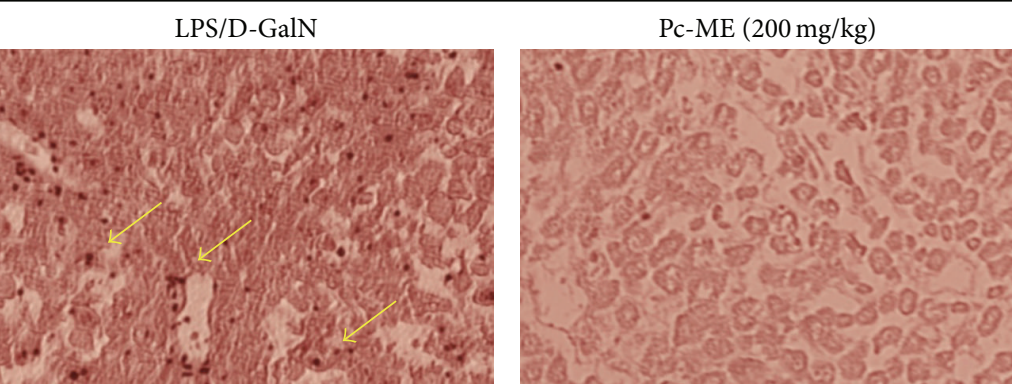

(c)

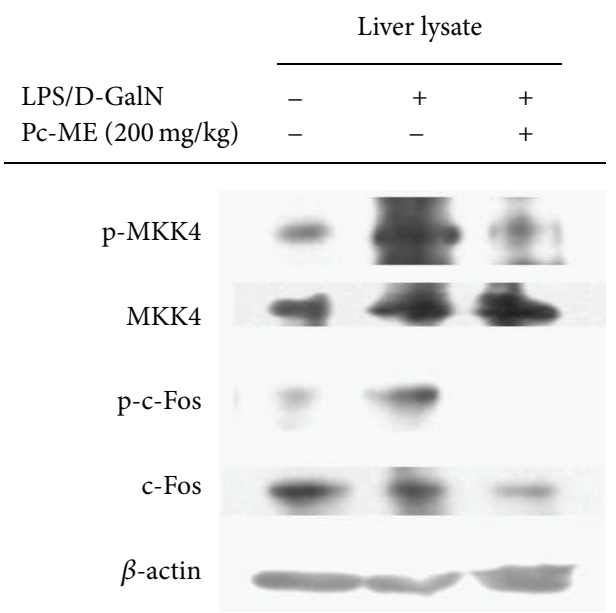

(d)

Figure 5: Effect of Pc-ME on LPS/D-GalN-induced hepatitis in mice. Mice were orally treated with Pc-ME (200 mg/kg) for six days before intraperitoneal injection of LPS/D-GalN. After $1 \mathrm{~h}$, mice were sacrificed to collect blood samples and liver sections for biochemical parameter analysis of (a) ALT, (b) AST, and (c) histopathological examination. (d) Phospho- or total protein levels of MKK4, c-Fos, and $\beta$-actin in liver lysates were determined by immunoblot analysis.

pharmacological target $[26,46-49]$. Therefore, the fact that Pc-ME is able to inhibit AP-1 pathway could be also accepted as a general anti-inflammatory mechanism of this plant.

As MAPKs play a vital role in the regulation of LPSinduced inflammation by controlling AP-1 activation [21], we examine the molecular inhibitory effects of Pc-ME on the AP1 pathway. Toward this goal, we analyzed the inhibitory effect of Pc-ME on MAPKs and their upstream signaling enzymes
[50]. The results of our study demonstrated that Pc-ME treatment time-dependently $(5,15,30$, and $60 \mathrm{~min})$ blocked ERK and JNK phosphorylation (Figure 4(a) left panel), potentially leading to significant attenuation of AP-1 activation in response to LPS. The dose-dependent (50 to $300 \mu \mathrm{g} / \mathrm{mL}$ ) inhibition pattern of the same MAPK phosphorylation by this extract (Figure 4(a) right panel) strongly supported our experimental condition and hypothesis. The phosphorylation 


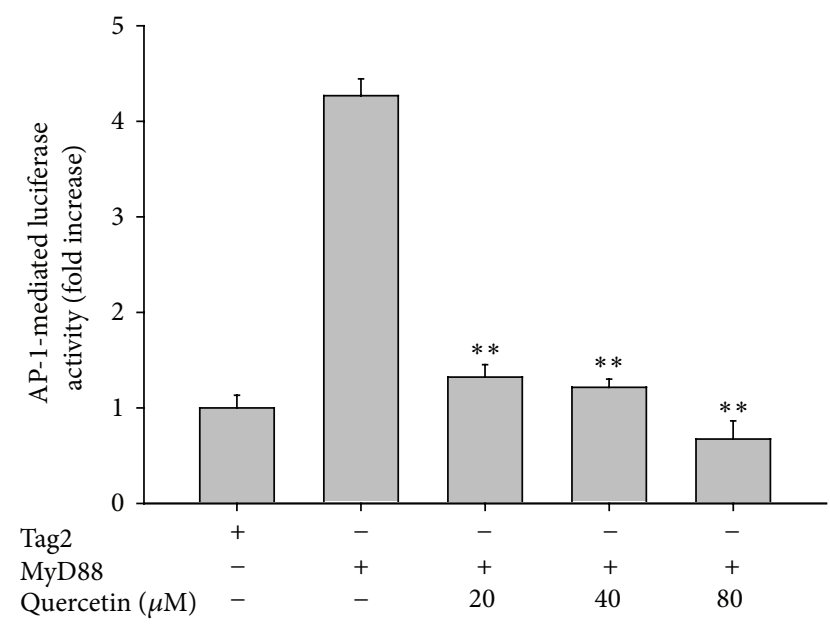

FIGURE 6: Effect of quercetin on the activation of upstream signaling enzymes of AP-1 in a reporter gene assay. The promoter binding activity of the transcription factor AP-1 was analyzed using a reporter gene assay in HEK293 cells transfected with plasmid constructs AP-1-Luc $(1 \mu \mathrm{g} / \mathrm{mL})$ and $\beta$-gal (as a transfection control) with $1 \mu \mathrm{g} / \mathrm{mL}$ of MyD88 in the presence of quercetin. Luciferase activity was measured using a luminometer. ${ }^{* *} P<0.01$ compared with control.

of MEK1/2 and MKK4, the upstream enzymes of ERK and JNK, respectively, was also strikingly suppressed by Pc-ME in LPS challenges of 2, 3, and 5 min (Figure 4(b)), confirming the MAPK inhibitory activity of this extract.

MAPK activation and subsequent AP-1 activation are strongly linked to the induction of hepatitis [22, 23]. So, we guess that AP-1-inhibitory extract, Pc-ME, is capable of attenuating hepatitis symptoms. To test this hypothesis, we employed LPS/D-GalN-intoxicated acute liver injury model, which is a classical system for screening hepatoprotective remedy in vivo [32]. Our previous study indicating that $\mathrm{Pc}-\mathrm{ME}$ can protect against $\mathrm{HCl} / \mathrm{EtOH}$-induced gastritis by inhibiting Src/Syk of NF- $\kappa$ B [17] has demonstrated the oral effectiveness of this extract. In the present study, expectedly, Pc-ME treatment $(200 \mathrm{mg} / \mathrm{kg})$ effectively ameliorated the LPS/D-GalN-induced liver damage (Figure 5(c)), including reversion of LPS/D-GalN-elevated hepatic ALT (Figure 5(a)) and AST (Figure 5(b)) enzyme levels. In the in vivo hepatic tissue, the upregulated phosphorylation of MKK4 and c-Fos (component of AP-1) was also noticeably blocked by Pc-ME treatment (Figure 5(d)), which strongly authenticated our findings. In addition, quercetin, a major antioxidative and anti-inflammatory compound of $P$. chinensis [17], also drastically diminished the AP-1 activation in a dose-dependent pattern (Figure 6), supporting that MAPK/AP-1-targeted antiinflammatory activity of Pc-ME could be quercetin-derived anti-inflammatory action. Although numerous numbers of medicinal plants or edible fruits such as Panax ginseng, Fagonia schweinfurthii, fermented soybean, Davilla elliptica, and Boesenbergia rotunda have been reported to show antihepatitis activities [51-55], only few plants are now clinically prescribed. It was revealed that Pc-ME is able to strongly suppress both NF- $\kappa \mathrm{B}$ [17] and AP-1 activity; we will further

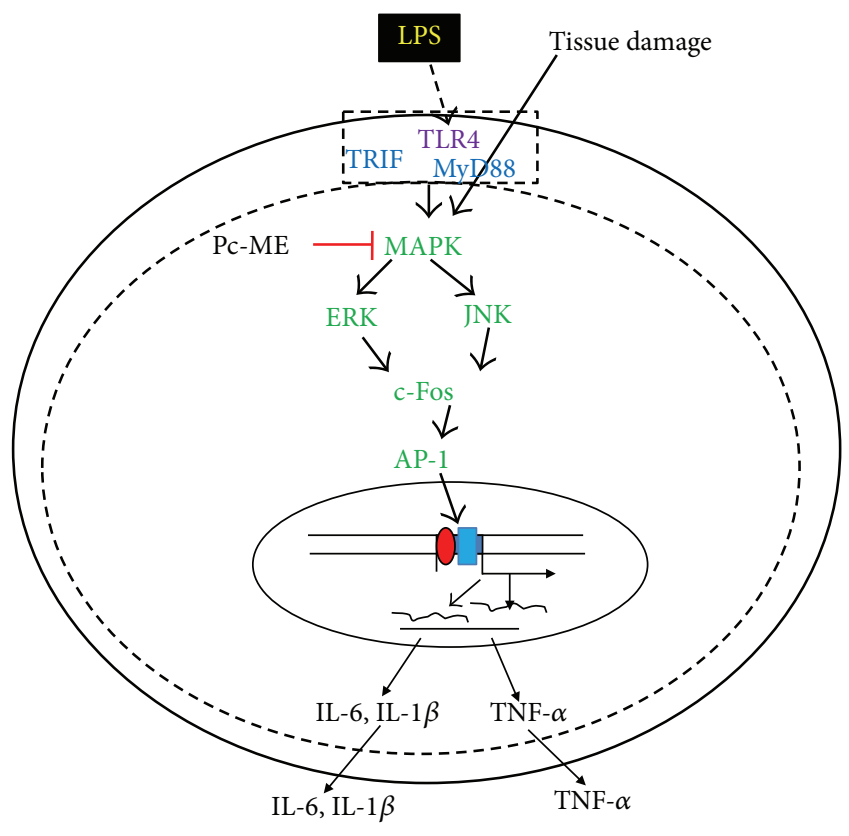

FIgURE 7: Putative mechanism of Pc-ME-mediated anti-inflammatory responses.

validate whether Pc-ME can be also clinically developed as a new antihepatitis herbal drug.

In summary, our in vivo and in vitro assays demonstrated that Pc-ME significantly reduced the levels of LPS-mediated proinflammatory cytokines (TNF- $\alpha$, IL- $1 \beta$, and IL-6), and that MAPK/AP-1 inactivation by this extract contributes to these inhibitory effects as summarized in Figure 7. The strong antihepatotoxic activity of Pc-ME in vivo was observed in a mouse model of LPS/D-GalN-induced liver injury, indicating that Pc-ME could potentially be used as a hepatoprotective remedy.

\section{Conflict of Interests}

The authors report no conflict of interests. The authors alone are responsible for the content and writing of the paper.

\section{Authors' Contribution}

Muhammad Jahangir Hossen and Seung Cheol Kim equally contributed to this work.

\section{Acknowledgment}

This study was supported by a grant of the Korean Health Technology R\&D Project, Ministry of Health \& Welfare, Republic of Korea (HI12C0050).

\section{References}

[1] C.-K. Tseng, C.-K. Lin, H.-W. Chang et al., "Aqueous extract of Gracilaria tenuistipitata suppresses LPS-induced NF- $\kappa \mathrm{B}$ and MAPK activation in RAW 264.7 and rat peritoneal macrophages and exerts hepatoprotective effects on carbon 
tetrachloride-treated rat," PLoS ONE, vol. 9, no. 1, Article ID e86557, 2014.

[2] H. C. Steel, R. Cockeran, R. Anderson, and C. Feldman, "Overview of community-acquired pneumonia and the role of inflammatory mechanisms in the immunopathogenesis of severe pneumococcal disease," Mediators of Inflammation, vol. 2013, Article ID 490346, 18 pages, 2013.

[3] M. Pasparakis, "Regulation of tissue homeostasis by NF-B signalling: implications for inflammatory diseases," Nature Reviews Immunology, vol. 9, no. 11, pp. 778-788, 2009.

[4] J.-K. Kim and G.-M. Park, "Indirubin-3-monoxime exhibits anti-inflammatory properties by down-regulating NF- $\kappa \mathrm{B}$ and JNK signaling pathways in lipopolysaccharide- treated RAW264.7 cells," Inflammation Research, vol. 61, no. 4, pp. 319-325, 2012.

[5] M. Ham and A. Moon, "Inflammatory and microenvironmental factors involved in breast cancer progression," Archives of Pharmacal Research, vol. 36, no. 12, pp. 1419-1431, 2013.

[6] M.-S. Lee, "Role of innate immunity in diabetes and metabolism: recent progress in the study of inflammasomes," Immune Network, vol. 11, no. 2, pp. 95-99, 2011.

[7] Y. Ayele, J.-A. Kim, E. Park et al., "A methanol extract of Adansonia digitata $\mathrm{L}$. leaves inhibits pro-inflammatory iNOS possibly via the inhibition of NF- $\kappa \mathrm{B}$ activation," Biomolecules and Therapeutics, vol. 21, no. 2, pp. 146-152, 2013.

[8] D. H. Kim, J. H. Chung, J. S. Yoon et al., "Ginsenoside Rd inhibits the expressions of $\mathrm{iNOS}$ and COX-2 by suppressing NF$\kappa \mathrm{B}$ in LPS-stimulated RAW264.7 cells and mouse liver," Journal of Ginseng Research, vol. 37, no. 1, pp. 54-63, 2013.

[9] M. Fujihara, M. Muroi, K.-I. Tanamoto, T. Suzuki, H. Azuma, and H. Ikeda, "Molecular mechanisms of macrophage activation and deactivation by lipopolysaccharide: roles of the receptor complex," Pharmacology and Therapeutics, vol. 100, no. 2, pp. 171-194, 2003.

[10] T. Yu, Y. J. Li, A. H. Bian et al., "The regulatory role of activating transcription factor 2 in inflammation," Mediators of Inflammation, vol. 2014, Article ID 950472, 10 pages, 2014.

[11] I.-T. Lee and C.-M. Yang, "Inflammatory signalings involved in airway and pulmonary diseases," Mediators of Inflammation, vol. 2013, Article ID 791231, 12 pages, 2013.

[12] E. D. Chan and D. W. H. Riches, "IFN- $\gamma+$ LPS induction of iNOS is modulated by ERK, JNK/SAPK, and p38mapk in a mouse macrophage cell line," The American Journal of Physiology-Cell Physiology, vol. 280, no. 3, pp. C441-C450, 2001.

[13] I. N. Crispe, “The liver as a lymphoid organ," Annual Review of Immunology, vol. 27, pp. 147-163, 2009.

[14] F. Tacke, T. Luedde, and C. Trautwein, "Inflammatory pathways in liver homeostasis and liver injury," Clinical Reviews in Allergy \& Immunology, vol. 36, no. 1, pp. 4-12, 2009.

[15] M. Y. Jia, Y. P. Jing, Q. Ai et al., "Potential role of catalase in mice with lipopolysaccharide/D-galactosamine-induced fulminant liver injury," Hepatology Research, vol. 44, no. 11, pp. 1151-1158, 2014.

[16] Q. Ai, Y. Jing, R. Jiang et al., "Rotenone, a mitochondrial respiratory complex i inhibitor, ameliorates lipopolysaccharide/Dgalactosamine-induced fulminant hepatitis in mice," International Immunopharmacology, vol. 21, no. 1, pp. 200-207, 2014.

[17] M. J. Hossen, K.-S. Baek, E. Kim et al., "In vivo and in vitro anti-inflammatory activities of Persicaria chinensis methanolic extract targeting Src/Syk/NF- $\kappa$ B," Journal of Ethnopharmacology, vol. 159, pp. 9-16, 2015.
[18] D. R. Luitel, M. B. Rokaya, B. Timsina, and Z. Münzbergová, "Medicinal plants used by the Tamang community in the Makawanpur district of central Nepal," Journal of Ethnobiology and Ethnomedicine, vol. 10, no. 1, article 5, 2014.

[19] W. M. May, The reproductive biology and cytotoxic activity of persicaria chinensis (L.) H. gross var. chinensis (Polygonaceae) [Dissertation], University of Malaya, 2012.

[20] S. M. Lai, D. Sudhahar, and K. Anandarajagopal, "Evaluation of antibacterial and antifungal activities of Persicaria chinensis leaves," International Journal of Pharmaceutical Sciences \& Research, vol. 3, p. 8, 2012.

[21] B. Veres, B. Radnai, F. Gallyas Jr. et al., "Regulation of kinase cascades and transcription factors by a poly(ADP-ribose) polymerase-1 inhibitor, 4-hydroxyquinazoline, in lipopolysaccharideinduced inflammation in mice," Journal of Pharmacology and Experimental Therapeutics, vol. 310, no. 1, pp. 247-255, 2004.

[22] M. Panteva, H. Korkaya, and S. Jameel, "Hepatitis viruses and the MAPK pathway: is this a survival strategy?" Virus Research, vol. 92, no. 2, pp. 131-140, 2003.

[23] A. Laliena, B. S. Miguel, I. Crespo, M. Alvarez, J. GonzálezGallego, and M. J. Tuñón, "Melatonin attenuates inflammation and promotes regeneration in rabbits with fulminant hepatitis of viral origin," Journal of Pineal Research, vol. 53, no. 3, pp. 270 278, 2012.

[24] S. E. Byeon, T. Yu, Y. Yang et al., "Hydroquinone regulates hemeoxygenase-1 expression via modulation of Src kinase activity through thiolation of cysteine residues," Free Radical Biology and Medicine, vol. 57, pp. 105-118, 2013.

[25] S. E. Byeon, T. Yu, Y. Yang et al., "Hydroquinone regulates hemeoxygenase-1 expression via modulation of Src kinase activity through thiolation of cysteine residues," Free Radical Biology and Medicine, vol. 57, pp. 105-118, 2013.

[26] Y. Yang, T. Yu, H.-J. Jang et al., "In vitro and in vivo antiinflammatory activities of Polygonum hydropiper methanol extract," Journal of Ethnopharmacology, vol. 139, no. 2, pp. 616625, 2012.

[27] M.-Y. Kim and J. Y. Cho, "20S-dihydroprotopanaxadiol, a ginsenoside derivative, boosts innate immune responses of monocytes and macrophages," Journal of Ginseng Research, vol. 37, no. 3, pp. 293-299, 2013.

[28] E. H. Jho, K. Kang, S. Oidovsambuu et al., "Gymnaster koraiensis and its major components, 3,5-di-O-caffeoylquinic acid and gymnasterkoreayne $\mathrm{B}$, reduce oxidative damage induced by tert-butyl hydroperoxide or acetaminophen in hepG2 cells," BMB Reports, vol. 46, no. 10, pp. 513-518, 2013.

[29] Y. Yang, T. Yu, Y. G. Lee et al., "Methanol extract of Hopea odorata suppresses inflammatory responses via the direct inhibition of multiple kinases," Journal of Ethnopharmacology, vol. 145, no. 2, pp. 598-607, 2013.

[30] S. Sun Back, J. Kim, D. Choi, E. S. Lee, S. Y. Choi, and K. Han, "Cooperative transcriptional activation of ATP-binding cassette sterol transporters ABCG5 and ABCG8 genes by nuclear receptors including Liver-X-Receptor," BMB Reports, vol. 46, no. 6, pp. 322-327, 2013.

[31] C. Liang, Y. Ding, S. B. Song et al., "Oleanane-triterpenoids from Panax stipuleanatus inhibit NF- $\kappa \mathrm{B}$," Journal of Ginseng Research, vol. 37, no. 1, pp. 74-79, 2013.

[32] J. Y. Cho, J. D. Yeon, J. Y. Kim, E. S. Yoo, Y. H. Yu, and M. H. Park, "Hepatoprotection by human epidermal growth factor (hEGF) against experimental hepatitis induced by D-galactosamine (DGalN) or D-GalN/lipopolysaccharide," Biological \& Pharmaceutical Bulletin, vol. 23, no. 10, pp. 1243-1246, 2000. 
[33] C.-W. Lee, F.-L. Yen, H.-W. Huang et al., "Resveratrol nanoparticle system improves dissolution properties and enhances the hepatoprotective effect of resveratrol through antioxidant and anti-inflammatory pathways," Journal of Agricultural and Food Chemistry, vol. 60, no. 18, pp. 4662-4671, 2012.

[34] T. Yu, J. Lee, Y. G. Lee et al., "In vitro and in vivo anti-inflammatory effects of ethanol extract from Acer tegmentosum," Journal of Ethnopharmacology, vol. 128, no. 1, pp. 139-147, 2010.

[35] Y.-H. Jeong, J.-W. Hyun, T. K. van Le, D.-H. Kim, and H.-S. Kim, "Kalopanaxsaponin A exerts anti-inflammatory effects in lipopolysaccharide-stimulated microglia via inhibition of JNK and NF- $\kappa$ B/AP-1 pathways," Biomolecules and Therapeutics, vol. 21, no. 5, pp. 332-337, 2013.

[36] M. Feldmann, "Many cytokines are very useful therapeutic targets in disease," The Journal of Clinical Investigation, vol. 118, no. 11, pp. 3533-3536, 2008.

[37] B. Kaminska, "MAPK signalling pathways as molecular targets for anti-inflammatory therapy-from molecular mechanisms to therapeutic benefits," Biochimica et Biophysica Acta-Proteins and Proteomics, vol. 1754, no. 1-2, pp. 253-262, 2005.

[38] Y. Yang, S. C. Kim, T. Yu et al., "Functional roles of p38 mitogenactivated protein kinase in macrophage-mediated inflammatory responses," Mediators of Inflammation, vol. 2014, Article ID 352371, 13 pages, 2014.

[39] Y. Yang, J. Lee, M. H. Rhee et al., "Molecular mechanism of protopanaxadiol saponin fraction-mediated anti-inflammatory actions," Journal of Ginseng Research, vol. 39, no. 1, pp. 61-68, 2015.

[40] L. A. J. O’Neill, K. A. Fitzgerald, and A. G. Bowie, “The TollIL-1 receptor adaptor family grows to five members," Trends in Immunology, vol. 24, no. 6, pp. 286-289, 2003.

[41] S. E. Byeon, J. Lee, B. C. Yoo et al., "P38-targeted inhibition of interleukin-12 expression by ethanol extract from Cordyceps bassiana in lipopolysaccharide-activated macrophages," Immunopharmacology and Immunotoxicology, vol. 33, no. 1, pp. 9096, 2011.

[42] M. H. Kim, D. S. Yoo, S. Y. Lee et al., “The TRIF/TBK1/IRF-3 activation pathway is the primary inhibitory target of resveratrol, contributing to its broad-spectrum anti-inflammatory effects," Pharmazie, vol. 66, no. 4, pp. 293-300, 2011.

[43] S. Ghosh and M. S. Hayden, "New regulators of NF- $\kappa$ B in inflammation," Nature Reviews Immunology, vol. 8, no. 11, pp. 837-848, 2008.

[44] R. Medzhitov and T. Horng, "Transcriptional control of the inflammatory response," Nature Reviews Immunology, vol. 9, no. 10, pp. 692-703, 2009.

[45] T. Kawai and S. Akira, "Toll-like receptors and their crosstalk with other innate receptors in infection and immunity," Immunity, vol. 34, no. 5, pp. 637-650, 2011.

[46] K. Mehla, S. Balwani, A. Kulshreshtha, D. Nandi, P. Jaisankar, and B. Ghosh, "Ethyl gallate isolated from Pistacia integerrima Linn. inhibits cell adhesion molecules by blocking AP-1 transcription factor," Journal of Ethnopharmacology, vol. 137, no. 3, pp. 1345-1352, 2011.

[47] T. Yu, H. M. Ahn, T. Shen et al., "Anti-inflammatory activity of ethanol extract derived from Phaseolus angularis beans," Journal of Ethnopharmacology, vol. 137, no. 3, pp. 1197-1206, 2011.

[48] H. S. Kim, A.-R. Kim, H. J. Park et al., "Morus bombycis Koidzumi extract suppresses collagen-induced arthritis by inhibiting the activation of nuclear factor- $\kappa \mathrm{B}$ and activator protein- 1 in mice," Journal of Ethnopharmacology, vol. 136, no. 3, pp. 392398, 2011.
[49] T. Yu, Y. J. Lee, H. M. Yang et al., "Inhibitory effect of Sanguisorba officinalis ethanol extract on $\mathrm{NO}$ and $\mathrm{PGE}_{2}$ production is mediated by suppression of NF- $\kappa \mathrm{B}$ and AP-1 activation signaling cascade," Journal of Ethnopharmacology, vol. 134, no. 1, pp. 11-17, 2011.

[50] M. Guha and N. Mackman, "LPS induction of gene expression in human monocytes," Cellular Signalling, vol. 13, no. 2, pp. 8594, 2001.

[51] S.-J. Seo, J. Y. Cho, Y. H. Jeong, and Y.-S. Choi, "Effect of Korean red ginseng extract on liver damage induced by shortterm and long-term ethanol treatment in rats," Journal of Ginseng Research, vol. 37, no. 2, pp. 194-200, 2013.

[52] A. Pareek, A. Godavarthi, R. Issarani, and B. P. Nagori, "Antioxidant and hepatoprotective activity of Fagonia schweinfurthii (Hadidi) Hadidi extract in carbon tetrachloride induced hepatotoxicity in HepG2 cell line and rats," Journal of Ethnopharmacology, vol. 150, no. 3, pp. 973-981, 2013.

[53] H. Mohd Yusof, N. M. Ali, S. K. Yeap et al., "Hepatoprotective effect of fermented soybean (nutrient enriched soybean tempeh) against alcohol-induced liver damage in mice," EvidenceBased Complementary and Alternative Medicine, vol. 2013, Article ID 274274, 8 pages, 2013.

[54] J. J. Campos, A. De Oliveira Azevedo, J. D. De Souza Filho, A. Castro Perez, and F. Castro Braga, "Bioguided isolation of myricetin-3-O- $\beta$-galactopyranoside with antinociceptive activity from the aerial part of Davilla elliptica St.-Hil," Journal of Ethnopharmacology, vol. 150, no. 1, pp. 270-274, 2013.

[55] S. M. Salama, M. A. Abdulla, A. S. Alrashdi, and A. H. A. Hadi, "Mechanism of hepatoprotective effect of Boesenbergia rotunda in thioacetamide-induced liver damage in rats," Evidence-based Complementary and Alternative Medicine, vol. 2013, Article ID 157456, 13 pages, 2013. 


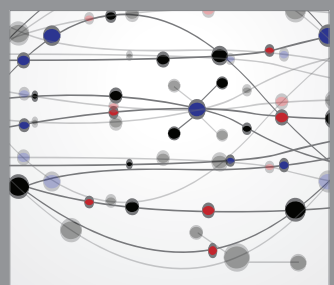

The Scientific World Journal
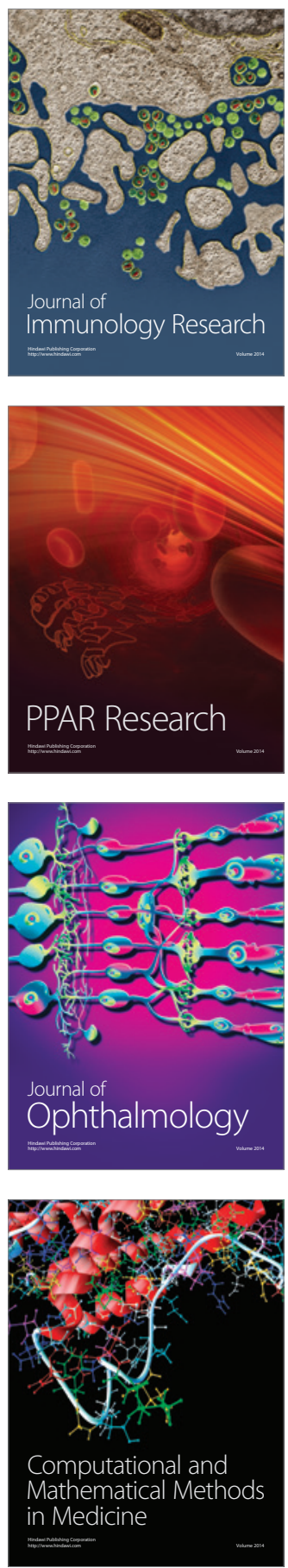

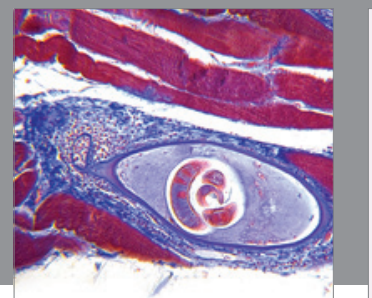

Gastroenterology

Research and Practice
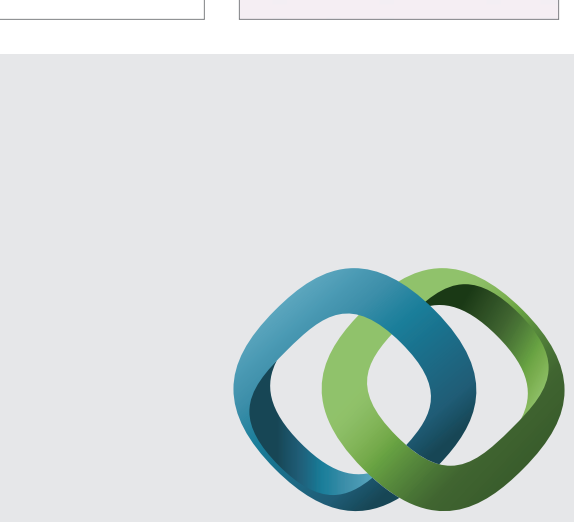

\section{Hindawi}

Submit your manuscripts at

http://www.hindawi.com
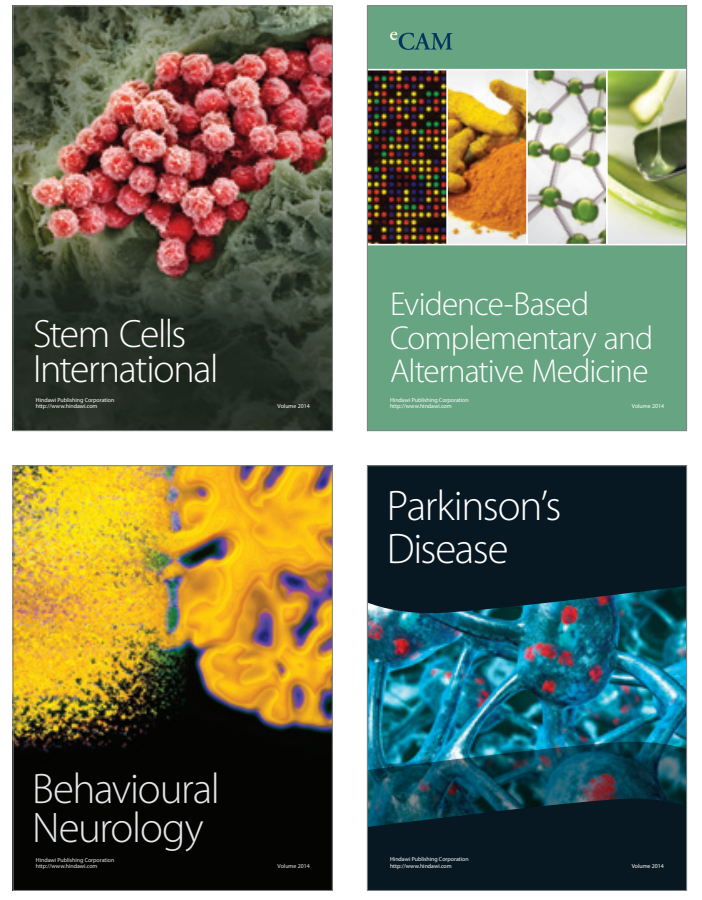
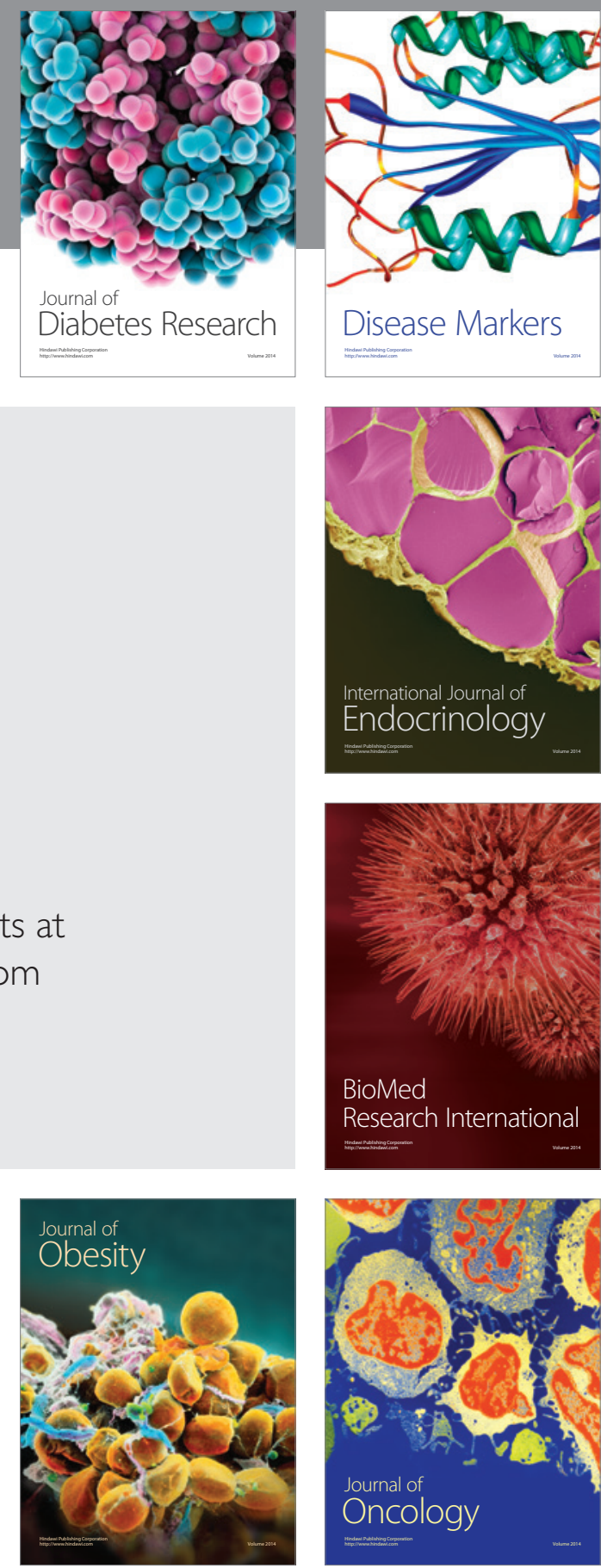

Disease Markers
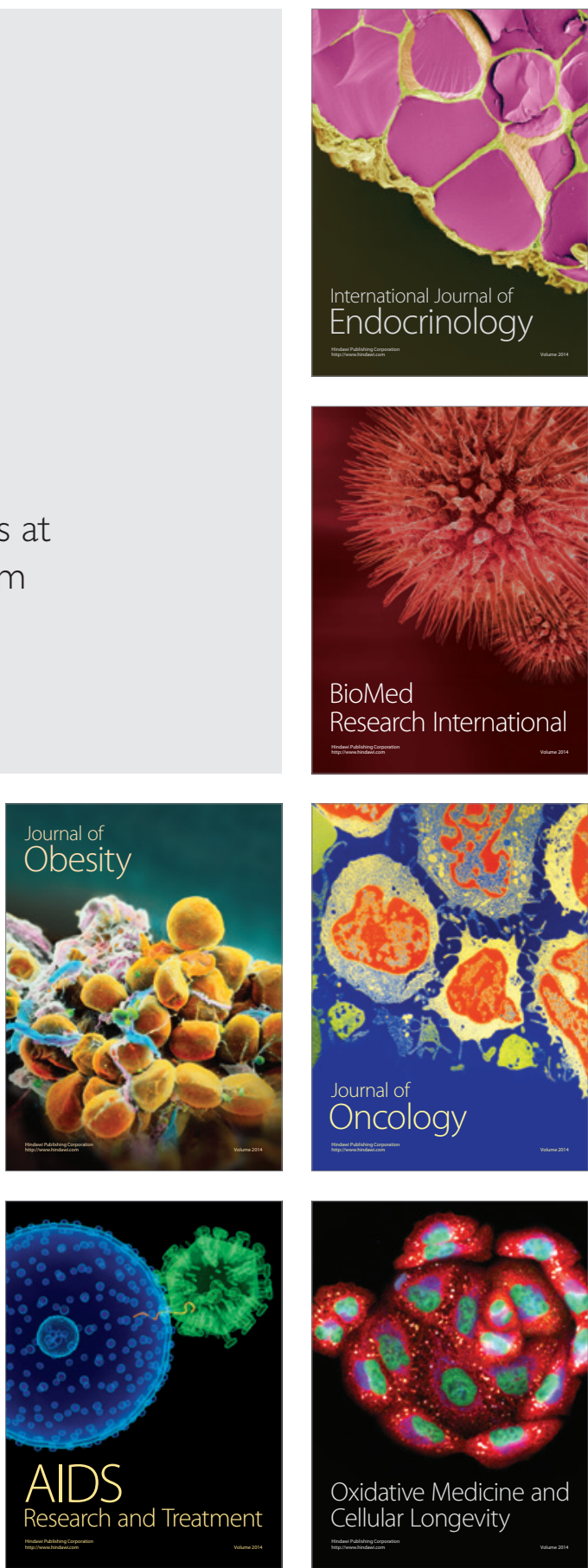